\title{
Mass Media and Their Relationship with Criminal Law in Albania
}

\author{
Rovena Kastrati, PhD Cand. \\ Faculty of Law, University of Tirana, Albania \\ rovena_kastrati@hotmail.com
}

\begin{abstract}
Information is the currency of democracy. (Thomas Jefferson), Freedom of expression is part of the so-called "negative liberty" that imply their guarantee by the Constitution as inviolable and for their realization require non-interference by the state or by private entities. Media uses this freedom, to achieve its objectives where not rarely goes beyond violating the other rights and freedoms prescribed in the Constitution. The power that people gave to media has made it a powerful pressure weapon, but often also a victim of its "sacred" mission, that of informing public about everything that happens. The aim of this paper is to present media reports with criminal law, which are dualistic reports: approaching and contradictory. It will also be presented an overview of the situation in Albania, where the media and its influence play a significant role in people's opinion and in the progress of criminal proceedings. In the first part of the paper I have mentioned the central role of the media in democracy and the benefits that community and society receives from media's freedom. Furthermore, in the second part I have been focusing on the other side of the coin addressing key points in which the media is presented as violating the human rights and interfering in criminal proceedings. In the third and last part I have submitted the role of investigative journalism as an important link in the media but in Albania is still unconsolidated.
\end{abstract}

Keywords: media, prevention of criminality, exceeding of powers, personal integrity violation, intrusion in the criminal process.

\section{Introduction}

Today we live in the modern era of digitization where the information industry is one of the most powerful and influential in the world. Media is a powerful tool for strengthening and consolidation of democracy in a country and its independence is indicative of the emancipation of society itself. Its role is constructive and multidimensional and consists in: information, education, entertainment, prevention and monitoring. As such, it finds expression in many areas of everyday life: in politics, arts, culture, economy and justice, and is seen as an open encyclopedia where all have access.

From one side, the media through monitoring, information and mass coverage, gives people an image of reality in which they live, it reports in real-time political, social, cultural and criminal events. Furthermore, comparison of opinions and research of truth, often makes media an ally of justice in preventing crime through the denunciations of violations of officials, their power abuse in the various institutions.

The press and other mass media, often and particularly in societies in transition, exceed its authority by violating the progress of the criminal process, risking the investigation, infringing privacy, or publishing sensitive data. These violations contain in their self criminal elements, but their consequences are not only criminal, but also social and moral since the publication of these elements involve the personal and social integrity of the person.

\section{Media as a powerful tool in fighting against crime.}

Everyone has the right to freedom of opinion and expression; this right includes freedom to hold opinions without interference and to seek, receive and impart information and ideas through any media and regardless of frontiers (Universal Declaration of Human Rights, Article 19, 1948). The freedom of a particular society can be determined by the freedom of the press and media. The first step, that usually take authoritarian or dictatorial governments, is to curtail or abolish the freedom of expression and media.

Media have a central role in democracy to inform the public and to review management of the public affairs without fear that can be pursued, indicted or pressured (Boyle, 2000). It can rightly be said that knowledge and information are necessary conditions for enabling citizens, state bodies, and institutions to perform their social works. 
The influence of the media has greatly increased in the recent years in regional range as well as in global range. In terms of social activation factor to fight against crime and anti-criminal social development, a special role belongs to the citizen's right to be informed about the phenomena of delinquent and criminal behavior in the environment.

Media exposure of crime and crime-related events can be an effective strategy for crime prevention, and useful tool for raising the awareness and educating the public about the social problems that are understated or overlooked. The role of crime prevention can be a source of information on the causes and trends of crime (Capobianco, 2008).

Various media campaigns on human trafficking, victim support, mobilization for the safety of women and children in cases of sexual abuse, etc., have contributed to the successful initiatives for crime prevention, for informing and raising public awareness about these negative phenomena (Capobianco, 2008). Especially social media is playing a key role in reporting the crime in connection with sex offenses where victims may be ashamed or afraid to talk face to face with the authorities (The Australian, 2012).

Media usually participates in the distribution of public information on the strategies of self-defense and security against crime. Websites of police departments and social media sites often provide excellent platforms to post advises on crime prevention and security against it. Through the establishment of blogs which are interactive, stimulate dialogue among public and police departments by providing an important feedback for the community (Dennis P. Rosenbaum; Amie M. Schuck; Lisa M. Graziano; Cody D. Stephens , 2007). Due to the impressive number of individuals who rely on the media for information about crime, media can be very effective for reporting certain types of crime as well as their strategies for prevention. Media campaigns for preventing theft of flats, road accidents and information on the dangers of illegal drug and alcohol usage, illustrate the ways in which the media can have an important role in crime prevention.

And finally, the media can play a democratic role when it comes to the question of crime prevention (Pekelsma, 2010). For more information that is made public, the media educates the population on certain issues, encouraging critical thinking of the population and promotes the responsibility of institutions, agencies, organizations and government. Media can enhance supervision or monitoring system for cases of police abuse and corruption, the judicial system in cases of arbitrary treatment and discrimination, as well as the education system.

\section{Coverage of the criminal phenomenon and violation of principles of criminal law, a dualistic conflict.}

Media are considered to have a dual character. On one side, the media reports about violation of human rights, however, on the other side, they make violations of human rights by spreading untrue allegations or instigating hatred. At the same time, freedom of expression can be conflicting with other rights such as: the right to a fair trial, to respect the private life, of conscience and religion etc. which are guaranteed by the International Covenant on Human Rights, the Constitution or other laws.

Some of the offenses that the media makes frequently in everyday life and which contradict the principles of criminal law are:

\section{a) Violation of the principle of presumption of innocence}

The Constitution of Albania, in article 30, determines that: "'Everyone is innocent until his guiltiness is not proven by a court's final decision." (Constitution of the Republic of Albania, 1998). The right to be presumed innocent is used against the suspects before the appearance of the criminal charges, before the trial and is kept in use until the guilt of the accused is confirmed, after the final appeal. Transmission of information from the media on the offense by linking the personal characteristics of the individual who presumed or committed the offense, even when this feature does not determine the qualification of the offense, establishes a practice that indirectly discriminates against individuals or communities because of these characteristics.

The presumption of innocence is not only a procedural guarantee in criminal trials, but its role is much wider. It is about the protection of anyone of the treatment of the bodies and state officials as guilty in committing a criminal offense before such a thing is verified by the court. Official sources of the Prosecutor General's Office show that in 5 years, 959 people, a large part of them, arrested by the request of police and consent of the prosecution have won acquittal by court. They are people who have appeared in the newspapers and television screens as different perpetrators, people who are "punished" by the media, in the "language" of the prosecution bodies (police and prosecutors), who even though win institutional innocence, their public image remains vulnerable. (Bregu, 2012). The pressure of time and negligence to 
respect until the end and fully professional standards and the language used by the media in such cases, leads us to the problem of violation of the presumption of innocence of citizens accused for offenses.

\section{b) Freedom of expression and independence of the judiciary}

The court must protect the confidentiality, provide information to the media, while the media should convey professionalism and honesty, without getting into the area that could be the courts barrier (Haxhaj, 2013). From the interaction of these two rights, in naturally way the conflict generates (inconsistency in appearance) between the need to protect the judicial activity to an "unnecessary external influence and protection of the right of information" (Kasmi, 2013). The cases when the court holds the hearing behind closed doors, excluding the media and public participation are provided under Article 340 of the Criminal Procedure Code: "The court decides to hold the court examination or some of its actions in camera: a) when the publicity may damage the social morality or may divulge data to be kept secret for the interest of the state, if this is requested by the competent authority, $b$ ) in case of behaviours which impair the normal performance of the hearing, $c$ ) when it is necessary to protect the witnesses or the defendant,ç) when necessary during the questioning of juveniles (Albania Law No. 7905,1995$)$.

Independence in information is- as important as- the independence of the judiciary but not rarely during their reporting, media deviate from their information mission (Haxhaj, 2013). The courts are accepted as independent and impartial to ensure the rights and legal obligations for resolution of the relative differences between subjects, therefore, the public has respect and trust in the capacity of the courts to fulfill this function. For this reason, the consequences of an attack (or an apparent attack) on impartiality can also bring a damage to the authority of the court. What should be avoided are the opinions especially about Judicial Corps issues that are on a trial and without completing issuance of a final decision. There were times that the media has brought opinions of judges on duty, prosecutors on duty, and in media attempt to analyze rightly an event have come to the wrong conclusions. Also, often we notice that a judge, head of a justice, thanks to the good image offered by media, reaches career advancement, or the opposite, the destruction of his career.

\section{c) Publication of sensitive data and confidential aspects of the media}

In printed and electronic media often are published pictures of defendants and juvenile witnesses accused or damaged by different criminal offenses. Such publications are prohibited by the law. Concretely, article 103 par. 4 of the Criminal Procedure Code states: "It is prohibited to publish personal details and photographs of minor defendants and witnesses, accused or injured by the criminal offence. The court may allow the publication only when the interest of the minor requires so or when the minor has reached the age of sixteen years" (Albania Law No. 7905,1995$)$.

The respect for the provision of the above is very important since disregard this legal requirement may be associated with adverse effects of psychological character, social and familiar and also in special cases may violate the right to privacy.

Not rarely, media has been in the focus of criticism as a result of the publication of detailed data even very sensitive data, such as the contents of messages on mobile and pictures, tools which should be available by the prosecution and occasionally they are under investigation. It is worth noting that, under Article 279 of the Criminal Procedure Code, Investigative actions are generally confidential and only the prosecutor is allowed to publish them with a reasonable decision.

\section{d) (Do not) Care of media coverage of minors in conflict with criminal justice}

The media can often cause a "second victimization" on crime victims or survivors by increasing their feelings of violation, disruption, and loss of control. Concerns that victims express about the media include: interviewing survivors in an inadequate time; and their footage and photographs of the crime scene; full typing the name or address of the victim; the past investigation of the victim etc. The issue becomes even more sensitive when children are protagonist. The most recent case was the scandal of Kajtazi sisters, who poisoned their parents and burned the apartment to escape and search for a better life. Although underage, media published their personal data such as name, place of residence and their pictures (Nazarko, 2015).

Journalists should be familiar with specific ethical standards for media reporting on children, such as ethical guidelines of UNICEF, guidelines and principles of the International Federation of Journalists, and Reporting and Information Guidelines for Minors, BBC editorial principles for children (changing the name of the child, visual blurring the identity of the minor, also the identity of the minor should not be published as well as the place where they live etc.). 
The interest of a state of physical and psychological well-being of an underage victim is so important that it justifies depriving the press and the public of their constitutional right to attend trials of criminal cases. For this reason, the court makes a decision, as appropriate, the development of closed-door trial is necessary to protect the welfare of minors from media exposure.

Bolivarian Republic of Venezuela, Law on "Protection of Children and Adolescents" said that: "To ensure respect for the best interest of the child, in case of a conflict between the rights and interests of a child or adolescent and the rights and interests of other equally legitimate, the former shall prevail" (Convention on theRights of the Child, 2007).

United States in a number of decisions have accepted that the interest of a state in physical and psychological welfare of an underage victim is so important that justifies depriving the press and the public of their constitutional right to attend trials of criminal cases, when the court makes a decision, where appropriate, the development of closed-door trial is necessary to protect the welfare of minors (Prince v. Massachusetts , 1944).

\section{Investigative journalism, as an analogue of the judiciary}

Investigative journalism is a form of journalism in which reporters deeply investigate a single topic of public interest, often including crime, political corruption or abusive acts of large companies or corporations. An investigative journalist may spend months or years investigating and prepare a report and it is a very important source and main thing in detailed information. It requires the implementation of in-depth investigations, on matters that affect the interests of citizens, violated corruption that grounds the state administration followed later in all cells of social organization.

Investigative journalism is characterized by features which differentiate it from any other kind of journalism. It is an expression of the degree of democracy and professionalism. It is not blackmail, pressure in the interests of the moment, also it is not a party, individual or electoral scoop.

Investigative journalism should be careful of manipulation. It should always be suspicious of the facts that are served and which its aim is manipulation. Verification of sources - is a necessity. Journalists should feel protected, but also knows how to convince others in the integrity of the evidence submitted by him, should not be afraid to face the lies, when its instrument is the truth.

When it comes to conducting successful investigations, Albania has its own specific problems. Too often, information that by law should be available are simply inaccessible. This, of course, that discourages investigative journalism (News, 2013). Another difficult hurdle for a successful investigative journalism in Albania is the reluctance of the principal editors to publish or broadcast articles or investigative chronicle. This is partly due to fears that the items or chronicles investigated in detail, especially those related to crime or corruption can lead to negative consequences - political or financial pressure. An important concern are also the working conditions and lack of incentives for investigative journalists (News, 2013).

No matter how hard it is, journalism remains essential for a functioning of a democratic society. If the media is the "gatekeeper" of democracy - investigative journalism is the eyes and ears of this gatekeeper. An ethic of information is always necessary. Information should be accurate, should not be subject to certain interests, individuals, specific groups of economic or political. Before starting the investigation - to verify the complete case for a journalist - the person who becomes the object of his investigation is considered - innocent.

\section{Conclusions}

Freedom of expression is considered as a precious legacy, as rightly considered even as a dangerous instrument. It constitutes one of the essential foundations of a democratic society and it is applicable not only for "information" and "ideas" that are favorably received or regarded as inoffensive but also those that offend, shock or disturb. These principles are of particular importance in terms of media. It can be a great source of strength, but, on the other hand, it is open to abuse.

In criminal law aspects is important because the press, radio, television, and other tools of public information and communication, not only that affected to a large number of people, but by their misuse can be done a number of offenses as for example: inciting hatred, incitement to aggressive war, war crimes or sexual crimes, severe forms of insult, defamation, disclosure or dissemination of personal or family data. These and other offenses that may be committed via the press and other means of public information, usually pose social threats. For this reason, the Criminal Code of the 
Republic of Albania, some of these offenses committed by means of public information are for example: inciting hatred, discord or national discrimination, racial, religious or ethnic, insult, slander, etc.., considers qualified forms of criminal offenses because the consequences that are caused are much more harmful than when they are performed in other tools and circumstances. In modern states, criminal legislation have been devised in various modes of criminal liability for offenses committed by public media. Most states have regulated this issue by special provisions of the criminal code.

Media through monitoring, information and mass coverage, gives the public an image of reality where he lives and beyond, makes an ally of justice through denunciations of officials violations, their abuses and abuses of various institutions, and this is the best part, but on the other hand, sometimes overcoming the limits of information or the inaccurate information leads to catastrophic consequences in the life of an individual or a society. For this reason it would be better to prosperous legal basis which allows the media to operate in Albania, by sanctioning the relevant provisions in criminal legislation and renewing existing ones, always without prejudice to the freedom of expression.

\section{References}

Prince v. Massachusetts, 321 U.S. 158 (U.S. Supreme Court January 31, 1944).

Universal Declaration of Human Rights, Article 19. (1948). Retrieved 2015, from United Nations of Human Rights: http://www.ohchr.org/

Albania Law No. 7905 . (1995, March 21). Retrieved October 2015, from World Intellectual Property Organisation: http://www.wipo.int

Constitution of the Republic of Albania. (1998, October 21). Retrieved January 2016, from Ministry of Defence: http://www.mod.gov.al/

Convention on theRights of the Child. (2007, November 13). Retrieved Decembre 2015, from United Nations: http://docstore.ohchr.org

(2012, November 15). Retrieved january 12, 2016, from The Australian: http://www.theaustralian.com.au

Boyle, K. (2000). Restrictions on the Freedom of Expression, in: Asia-Europe Foundation (ASEF), TheThird Informal ASEM Seminar on Human Rights. Singapore.

Bregu, Z. (2012, November 25). Media mes raportimit të krimit, gjyqit publik dhe të drejtat e njeriut (Media between crime reporting, public trial and human rights). Retrieved Januar 2016, from Media për Median: https://mediapermedian.wordpress.com

Capobianco, L. (2008). The Media, Crime Prevention and Urban Safety: A Brief Discussion on Media Influence and Areas for Further Exploration. Montreal.

Dennis P. Rosenbaum; Amie M. Schuck; Lisa M. Graziano; Cody D. Stephens . (2007). Measuring Police and Community Performance Using Web-Based Surveys:Findings From the Chicago Internet Project. Chicago: University of Illinois .

Haxhaj, R. (2013). Qasja e Publikut dhe e Mediave në Procedurat Gjyqësore: Mediat Ndërmjet Transparencës dhe Dhënies së Informacionit të Gabuar(Public an Media Acces on Tial Procedures: Media Between Transparency and Wrong Disclosure of Information). Revista Shqiptare për Studime Ligjore (Albanian Journal of Legal Studies), 7, 73:81.

Kasmi, B. (2013, July 21). Media dhe Gjyqesori, Raportet dhe Prespektivat. Retrieved september 2015, from Panorama Online: http://www.panorama.com.al

Kodi Gazetarise Investigative (Investigative Journalism Code). (n.d.). Retrieved January 2016, from Instituti Shqiptar i Medias ( Albanian Media Institute): http://www.institutemedia.org/

Nazarko, M. (2015, August 20). Ndihme per Motrat Kajtazi (Help for Kajtazi Sisters). Retrieved December 2015, from Panorama Online: http://www.panorama.com.al/ 
News, O. (2013, Novembre 23). Gazetaria investigative në Shqipëri, OSBE tryezë me gazetarë dhe analistë (Investigative journalism in Albania, OSCE roundtable with journalists and analysts). Retrieved november 2015, from Ora News: http://www.oranews.tv/

Pekelsma, S. (2010, July 5). Retrieved January 10, 2016, from European Urban Knowledge Network: http://www.eukn.eu 